\title{
Common genetic variants on chromosome 9p21 predict perioperative myocardial injury after coronary artery bypass graft surgery
}

\author{
Kuang-Yu Liu, PhD, ${ }^{\mathrm{a}, *}$ Jochen D. Muehlschlegel, MD, ${ }^{\mathrm{a}, *}$ Tjörvi E. Perry, MD, ${ }^{\mathrm{a}}$ Amanda A. Fox, MD, ${ }^{\mathrm{a}}$ \\ Charles D. Collard, MD, ${ }^{\mathrm{b}}$ Simon C. Body, MBChB, MPH, ${ }^{\mathrm{a}}$ and Stanton K. Shernan, MD ${ }^{\mathrm{a}}$
}

Objective: Approximately $10 \%$ of patients undergoing cardiac surgery have perioperative myocardial injury. A recent genome-wide association study identified an association between myocardial infarction in nonsurgical populations and common genetic variants on chromosome 9p21. We hypothesized that these variants are also associated with perioperative myocardial injury after isolated primary coronary artery bypass graft surgery.

\begin{abstract}
Methods: In a prospective observational study of 846 Caucasian patients undergoing primary coronary bypass surgery at 2 US centers, we genotyped 61 linkage-disequilibrium tagging single nucleotide polymorphisms, encompassing $436 \mathrm{kbp}$ of the $9 \mathrm{p} 21$ region. A multivariable logistic model was used to adjust for previously identified clinical covariates of perioperative myocardial injury. Perioperative myocardial injury was defined as a postoperative day 1 cardiac troponin I in the top 10th percentile $(>9.13 \mu \mathrm{g} / \mathrm{L})$ of the cohort. Multiple testing of single nucleotide polymorphisms was corrected for with family-wise errors.
\end{abstract}

Results: Prior myocardial infarction and longer cardiopulmonary bypass time were significant independent predictors of perioperative myocardial injury. Levels of postoperative cardiac troponin I were incrementally increased for each additional copy of the risk alleles of 3 single nucleotide polymorphisms: rs 10116277, rs6475606, and rs2383207. Adjusted additive odds ratios ranged between 1.64 and 1.79 (asymptotic $P$ value between $3.7 \times$ $10^{-3}$ and $6 \times 10^{-4}$ ) and remained significantly associated with perioperative myocardial injury even after accounting for clinical covariates including severity of coronary disease, and multiple comparisons.

Conclusions: We have now demonstrated that common genetic variants in the same 9p21 locus, previously known to be associated with myocardial infarction in nonsurgical populations, are also associated with perioperative myocardial injury after coronary artery bypass grafting. Further investigation is warranted to elucidate functional mechanisms. (J Thorac Cardiovasc Surg 2010;139:483-88)

Supplemental material is available online.

Multiple epidemiologic studies have documented a significant heritability for coronary artery disease (CAD) and myocardial infarction. ${ }^{1}$ Using an unbiased genome-wide approach, recent studies identified an association between cardiovascular disease, CAD or myocardial infarction,

\footnotetext{
From the Department of Anesthesiology, ${ }^{a}$ Perioperative and Pain Medicine, Brigham and Women's Hospital, Harvard Medical School, Boston, Mass; and Baylor College of Medicine, ${ }^{\mathrm{b}}$ Division of Cardiovascular Anesthesia, the Texas Heart Institute, Saint Luke's Episcopal Hospital, Houston, Tex.

Disclosures: These studies were supported in part by the Bayer Fellowship in Blood Conservation, Biosite Inc. (San Diego, CA); NIH (HL-068774 and NCRR M01 02558) and a Society of Cardiovascular Anesthesiologists Research Starter Grant.

* K.-Y.L. and J.D.M. contributed equally to this article.

Received for publication Feb 25, 2009; revisions received May 20, 2009; accepted for publication June 20, 2009; available ahead of print Oct 12, 2009.

Address for reprints: Jochen D. Muehlschlegel, MD, Department of Anesthesiology, Perioperative and Pain Medicine, CWN L1, Brigham and Women's Hospital, 75 Francis St, Boston, MA 02115 (E-mail: jmuehlschlegel@partners.org).

$0022-5223 / \$ 36.00$

Copyright (c) 2010 by The American Association for Thoracic Surgery

doi:10.1016/j.jtcvs.2009.06.032
}

with common genetic variants on chromosome 9p21 in nonsurgical populations. ${ }^{2-4}$ Although the responsible molecular genetic determinants remain largely unidentified, these variants are adjacent to genes for the cyclin-dependent kinases $C D K N 2 A / B$, which play a critical role in regulating cell aging, cell proliferation, and apoptosis, ${ }^{5-8}$ as well as ANRIL, a large antisense noncoding RNA gene, shown to be expressed in cell types integral to atherosclerosis. ${ }^{9-11}$

Perioperative myocardial injury (PMI), which afflicts nearly 1 million people annually during or after noncardiac surgery worldwide, ${ }^{12}$ has conventionally been associated with transient myocardial ischemia and reperfusion owing to aortic occlusion, cardiotomy, and an obligatory acute inflammatory response associated with cardiopulmonary bypass (CPB). Although a few limited studies have implicated a heritable risk of PMI, ${ }^{13,14}$ variants in the 9 p21 region have not yet been examined for an association with this adverse perioperative outcome. Therefore, we hypothesized that variants in the 9p21 region are also independently associated with PMI after isolated primary coronary artery bypass graft $(\mathrm{CABG})$ surgery with $\mathrm{CPB}$.

\section{METHODS}

Two institutions (Brigham and Women's Hospital and Texas Heart Institute, recruited patients within a single study structure known as the CABG 


$$
\begin{aligned}
& \text { Abbreviations and Acronyms } \\
& \begin{aligned}
\text { CABG } & =\text { coronary artery bypass graft } \\
\text { CAD } & =\text { coronary artery disease } \\
\text { CPB } & =\text { cardiopulmonary bypass } \\
\text { cTNI } & =\text { cardiac troponin I } \\
\text { PMI } & =\text { perioperative myocardial injury } \\
\text { POD } & =\text { postoperative day } \\
\text { SNP } & =\text { single nucleotide polymorphism }
\end{aligned}
\end{aligned}
$$

Genomics Program (http://clinicaltrials.gov/show/NCT00281164). After August 2001, we prospectively enrolled patients aged 20 to 90 years undergoing nonemergency primary CABG surgery with $\mathrm{CPB}$, without other concurrent surgery. Patients with a preoperative hematocrit value of less than $25 \%$ or transfusion of leukocyte-rich blood products within 30 days before the operation were not enrolled. To avoid potential population stratification, we restricted analysis to subjects who self-reported 4 Caucasian grandparental ancestry. Study protocols were approved by the respective institutional review boards, and participants were enrolled after providing informed written consent. The funding agencies had no involvement in study design, data interpretation, or data analysis.

\section{Data Collection}

At each site, we recorded patient demographics, perioperative risk factors, medications, and postoperative outcomes using study-specific case report forms. Blood samples were drawn before induction of general anesthesia, after administration of post-CPB protamine, and on the mornings of postoperative days (PODs) 1 to 5. Serum and plasma were stored in vaporphase liquid nitrogen until analysis for cardiac troponin I (cTnI), B-type natriuretic peptide, and creatine kinase $\mathrm{MB}$ fraction on a sandwich immunoassay on a Triage platform using monoclonal and polyclonal antibodies (Biosite Inc, San Diego, Calif) at a single core facility. Myocardial injury was defined as POD $1 \mathrm{cTnI}$ in the top 10th percentile $(>9.13 \mu \mathrm{g} / \mathrm{L})$.

\section{Genotyping}

DNA was extracted from white blood cells by standard procedures. Linkage-disequilibrium tagging single-nucleotide polymorphisms (SNPs) between chromosome 9 positions 21,930,588-22,366,970 (NCBI Genome Build 36 assembly) encompassing the originally identified 9p21 region with minor allele frequencies of $5 \%$ or greater in the HapMap Caucasian cohort were identified using Tagger. ${ }^{15}$ Overall, 61 tagging SNPs that described $70.8 \%$ of the variation with a mean $r^{2}$ of 0.8 in the 394 HapMapidentified SNPs were genotyped (Supplemental Table 1) using the Golden Gate assay with an Illumina Bead Station 500 G system (Illumina, San Diego, Calif), in accordance with the manufacturer's standard recommendations.. The raw data were analyzed with the clustering algorithm of the Illumina BeadStudio software and individual examination of all intensity plots, with manual curation of genotype calls. SNPs with genotyping call rate less than $95 \%$, with significant deviation from Hardy-Weinberg equilibrium $(P<.001$ in controls $)$ and nonrandom missingness $(P<.05)$ between cases and controls, were excluded from subsequent analysis.

\section{Statistical Analysis}

Categorical and continuous demographic characteristics were compared between groups with likelihood ratio $\chi^{2}$ and Wilcoxon rank sum tests, respectively. A multivariable logistic model was used to derive perioperative and demographic variables associated with PMI, including severity of CAD. Factors previously associated with PMI after cardiac surgery in prior studies, including acute coronary syndrome, were forced into the logis- tic regression model along with clinically relevant variables using stepwise selection. PLINK (version 1.04) and SAS (version 9.1.3; SAS Institute, Inc, Cary, NC) were used for genetic association analysis. Hardy-Weinberg equilibrium was evaluated by an exact test. After application of genotype quality control criteria, univariate analyses were carried out for each SNP to test the null hypothesis of no association between marker polymorphism and PMI, based on log-additive genetic models. Adjusted odds ratios of every SNP for PMI were estimated by the aforementioned multivariable logistic regression model. To correct for multiple testing, we report tests of significance as family-wise empirical $P$ values based on permuting case-control status.

\section{RESULTS}

Between August 2001 and August 2006, 877 Caucasian patients were genotyped as described in the Methods section. Thirty-one patients had genotyping rates of less than $90 \%$ or were missing biomarkers and were excluded.

Patient characteristics stratified by PMI status after primary CABG surgery are shown in Table 1. Eighty-five patients (top 10th percentile) had a POD $1 \mathrm{cTnI}$ level greater than $9.13 \mu \mathrm{g} / \mathrm{L}$ and therefore were classified as having PMI. Patients who had a history of myocardial infarction, lower preoperative left ventricular ejection fraction, longer CPB duration or aortic crossclamp time, or were not receiving preoperative angiotensin-converting enzyme inhibitors were more likely to have PMI. Similarly, elevated preoperative $\mathrm{cTnI}$ and creatine kinase $\mathrm{MB}$, but not preoperative B-type natriuretic peptide, were associated with a higher risk of PMI. The degree of coronary artery stenosis by angiography or the number of vessels grafted intraoperatively was not significantly different between patients who had PMI and those who did not. Patients with PMI were hospitalized for 1 additional day but did not have significant differences in all-cause mortality. Multivariable logistic model identified recent myocardial infarction and longer duration of CPB time as significant independent predictors of PMI (Table 2).

All 61 SNPs passed quality control by genotyping call rate, Hardy-Weinberg equilibrium, and nonrandom missingness. One SNP had an observed minor allele frequency of $1 \%$ and was excluded from further analysis, leaving a total of 60 remaining SNPs that were included in the analysis (Table E1). Levels of postoperative cTnI were incrementally increased for each additional copy of the minor allele (ie, the risk allele in our cohort) of rs10116277 (Figure 1), rs6475606, and rs2383207. These three SNPs within the coding region of ANRIL were also significantly associated with PMI, even after accounting for clinical covariates and multiple comparisons using an additive genetic model (Table 3). Careful inspection of model fit statistics, based on commonly used statistical criteria (likelihood ratio, Nagelkerke $R^{2}$, Akaike information criterion, and SchwarzBayesian information criterion), revealed very substantial incremental improvement of adding these 9p21 variants into the clinical predictive multivariable model of PMI. 
TABLE 1. Demographics and clinical characteristics

\begin{tabular}{|c|c|c|c|}
\hline & $\begin{array}{c}\mathrm{cTnI}<9.13 \\
\mu \mathrm{g} / \mathrm{L}(\mathrm{N}=761) \\
\end{array}$ & $\begin{array}{c}\text { cTnI } \geq 9.13 \\
\mu \mathrm{g} / \mathrm{L}(\mathrm{N}=\mathbf{8 5})\end{array}$ & $\begin{array}{c}P \\
\text { value }\end{array}$ \\
\hline \multicolumn{4}{|l|}{ Demographics } \\
\hline Gender (N, \% male) & $628(83)$ & $67(79)$ & .374 \\
\hline Institution $(\mathrm{N}, \%)$ & $615(81)$ & $70(82)$ & .884 \\
\hline Age (y) & $64(57-72)$ & $65(59-74)$ & .291 \\
\hline BMI $\left(\mathrm{kg} / \mathrm{m}^{2}\right)$ & $28.5(25.8-31.9)$ & $28.3(25.0-32.7)$ & .972 \\
\hline \multicolumn{4}{|l|}{ Medical history } \\
\hline LVEF preop (\%) & $55(45-60)$ & $50(45-60)$ & .014 \\
\hline $\begin{array}{l}\text { Diabetes } \\
\text { (insulin-dependent or } \\
\text { non-insulin dependent; \%) }\end{array}$ & $203(27)$ & $16(19)$ & .150 \\
\hline $\begin{array}{l}\text { Pulmonary disease } \\
\text { (COPD, asthma; \%) }\end{array}$ & $32(4)$ & $3(4)$ & .767 \\
\hline Creatinine $(\mathrm{mg} / \mathrm{dL})$ & $1(0.9-1.2)$ & $1.1(0.9-1.3)$ & .401 \\
\hline Hematocrit $(\%)$ & $40(34-44)$ & $40(37-43)$ & .520 \\
\hline Hypertension ( $\%)$ & $570(75)$ & $60(71)$ & .360 \\
\hline Hypercholesterolemia (\%) & $581(76)$ & $62(74)$ & .591 \\
\hline \multicolumn{4}{|c|}{ Coronary stenosis $(>50 \%)$ regions } \\
\hline$\leq 2$ & $165(22)$ & $14(16)$ & \\
\hline 3 & $388(51)$ & $49(58)$ & \\
\hline$\geq 4$ & $208(27)$ & $22(26)$ & .417 \\
\hline $\begin{array}{l}\text { Previous myocardial } \\
\text { infarction }\end{array}$ & $309(41)$ & $46(54)$ & .021 \\
\hline $\begin{array}{l}\text { Myocardial infarction } \\
\text { within prior } 2 \mathrm{wk}(\%)\end{array}$ & $119(16)$ & $26(31)$ & .001 \\
\hline \multicolumn{4}{|l|}{ Medications-preoperative ( $N, \%)$} \\
\hline ACE inhibitor & $30(35)$ & $362(48)$ & .039 \\
\hline$\beta$-blocker & $587(77)$ & $66(78)$ & .915 \\
\hline $\mathrm{Ca}^{++}$antagonist & $103(14)$ & $8(9)$ & .396 \\
\hline Aspirin & $568(75)$ & $60(71)$ & .434 \\
\hline HMG CoA reductase inhibitor & $583(77)$ & $60(71)$ & .229 \\
\hline \multicolumn{4}{|c|}{ Biomarkers-preoperative } \\
\hline $\mathrm{BNP}(\mu \mathrm{g} / \mathrm{L})$ & $18(5-56)$ & $26(6-72)$ & .112 \\
\hline CKMB $(\mu \mathrm{g} / \mathrm{L})$ & $0.5(0.2-1.2)$ & $0.9(0.3-3.0)$ & $<.001$ \\
\hline $\mathrm{cTnI}(\mu \mathrm{g} / \mathrm{L})$ & $0.01(0-0.03)$ & $0.03(0-0.9)$ & $<.001$ \\
\hline \multicolumn{4}{|l|}{ Surgery } \\
\hline \multicolumn{4}{|l|}{ No. of grafts $(\mathrm{N}, \%)$} \\
\hline$\leq 2$ & $119(16)$ & $13(15)$ & \\
\hline 3 & $356(47)$ & $41(48)$ & \\
\hline$\geq 4$ & $286(38)$ & $31(36)$ & .968 \\
\hline CPB duration (min) & $94(66-117)$ & $108(85-138)$ & $<.001$ \\
\hline $\begin{array}{c}\text { Aortic crossclamp } \\
\text { duration (min) }\end{array}$ & $71(41-90)$ & $82(61-107)$ & $<.001$ \\
\hline \multicolumn{4}{|l|}{ Postoperative data } \\
\hline $\operatorname{HLOS}(\mathrm{d})$ & $7(6-9)$ & $8(6-10)$ & .001 \\
\hline Mortality $(\%, N)$ up to $5 \mathrm{y}$ & $52(7)$ & $10(12)$ & .120 \\
\hline
\end{tabular}

$c T n I$, Cardiac troponin I; $B M I$, body mass index; $L V E F$, left ventricular ejection fraction; $C O P D$, chronic obstructive pulmonary disease; $A C E$, angiotensin-converting enzyme; $H M G C O A$, 3-hydroxy-3-methyl-glutaryl coenzyme A reductase; $B N P$, B-type natriuretic peptide; $C K M B$, creatinine kinase $\mathrm{MB}$ fraction; $C P B$, cardiopulmonary bypass; $H L O S$, hospital length of stay.

Significant pairwise linkage disequilibrium was present in the region that precludes identification of a single associated variant (Figure 2). The SNP rs10811661, previously associ- ated with type 2 diabetes, ${ }^{16}$ had no association with PMI in our cohort and is also not in linkage disequilibrium with SNPs associated with PMI (Figure 2).

\section{DISCUSSION}

We have shown that variants on $9 \mathrm{p} 21$ previously associated with cardiovascular disease, CAD or myocardial infarction in ambulatory nonsurgical populations, are also associated with PMI after CAGB surgery with CPB. Furthermore, we confirmed that this association is independent of type 2 diabetes, and with the SNP rs10811661, previously associated with type 2 diabetes. ${ }^{16}$ Additionally, although variants within the 9p21 chromosonal locus have been associated with CAD in nonsurgical patients, the association we observed between 9p21 SNPs and PMI in our cohort was independent of CAD severity assessed by coronary angiogram. Similarly, while the SNPs associated with CAD and $\mathrm{MI}$ in nonsurgical patients are the same as for PMI in our cohort with severe $\mathrm{CAD}$, the specific risk alleles in each population are different. Nonetheless, to our knowledge, this is the first report demonstrating a unique and novel association between 9 p21 variants and any adverse perioperative outcome.

Despite considerable efforts by geneticists, the underlying mechanisms of the association of 9p21 with cardiovascular disease, CAD and myocardial infarction, have not been elucidated. The 9p21 region encompassing the identified SNPs is flanked by two recombination hotspots and is adjacent to the cyclin-dependent kinases $C D K N 2 A$ and $C D K N 2 B$, which have important roles in cell cycle regulation. ${ }^{11}$ Through their role in transforming growth factor $\beta$-induced growth inhibition, the cyclin-dependent kinases have been implicated in the pathogenesis of atherosclerosis, ${ }^{17}$ although their role in acute events such as myocardial infarction has yet to be elucidated. A recent study found that probands with the $9 \mathrm{p} 21$ risk allele had decreased expression of the $C D K N 2 A / 2 B$ locus in peripheral blood leukocytes ${ }^{18}$ and that inactivation of $C D K N 2 B$ and/or $C D K N 2 A$ allows cells to escape cell cycle arrest or become senescent. ${ }^{11}$ Senescent cells are resistant to programmed cell death, leading to accumulation of these cells in injured tissue with substantial effects on healthy neighboring tissue. ${ }^{19}$ Hypothetically, ischemic injury may unmask and accelerate the effects of the 9p21 variants with at-risk patients more susceptible to senescent cell accumulation. Also of interest, the associated SNPs lie within ANRIL, a large antisense noncoding RNA gene, considered to be operating in the transcriptional control repertoire of the cell and expressed in tissues and cell types affected by atherosclerosis. ${ }^{10}$ Experimental evidence suggests possible coordinated transcriptional regulation of ANRIL mediated by cyclin-dependent kinase. $^{10}$

In addition to being a risk factor for $\mathrm{CAD}$ and having an association with myocardial infarction, variation in $9 \mathrm{p} 21$ 
TABLE 2. Multivariable clinical predictor model of perioperative myocardial injury

\begin{tabular}{lcc}
\hline \multicolumn{1}{c}{ Predictor } & Odds ratio $(\mathbf{9 5} \%$ CI) & $\boldsymbol{P}$ value \\
\hline Age (decile) & $1.11(0.88-1.39)$ & .378 \\
Gender (male) & $1.25(0.69-2.28)$ & .457 \\
Institution & $0.66(0.86-3.2)$ & .131 \\
Preoperative HMG CoA reductase & $0.73(0.44-1.22)$ & .232 \\
$\quad$ inhibitor use & & \\
Myocardial infarction within & $2.29(1.37-3.84)$ & .002 \\
$\quad$ previous 2 weeks & & \\
Coronary stenosis $(>50 \%)$ regions & 1 & \\
$\quad \leq 2$ & $1.14(0.60-2.18)$ & \\
3 & $0.97(0.47-2.01)$ & .80 \\
$\quad \geq 4$ & $1.14(1.08-1.21)$ & $<.0001$ \\
CPB time & $1.56(0.16-15.5)$ & .70 \\
Preoperative creatinine &
\end{tabular}

Important clinical and demographic variables from Table 1 selected by stepwise regression and entered into multivariable model. $C I$, Confidence interval; $H M G$ $C o A$, 3-hydroxy-3-methyl-glutaryl coenzyme A; $C P B$, cardiopulmonary bypass, in increments of 10 mimutes.

has also been associated with carotid atherosclerosis, progression of atherosclerosis, ${ }^{20}$ and abdominal aortic aneurysm..$^{21,22}$ Surprisingly, 9p21 variants are also associated with intracranial aneurysms, ${ }^{22}$ a disease not mediated by atherosclerosis. However, the role of variants in 9p21 does not appear to be mediated through vascular reactivity. ${ }^{23}$ This lack of association with vascular reactivity, along with the relation of the 9 p21 locus to aneurysms, suggests a mechanism more complex than simply promoting atherosclerotic plaque development.

The etiology of PMI occurring during cardiac surgery is markedly different from myocardial infarction occurring in ambulatory populations. Nonsurgical myocardial infarction is predominantly associated with prolonged stress-induced myocardial ischemia (ie, non-ST-segment elevation myocardial infarction) or coronary plaque disruption (ie, ST-segment elevation myocardial infarction). ${ }^{24-26}$ By contrast, $\mathrm{CABG}$ surgery with $\mathrm{CPB}$ requires aortic cross-

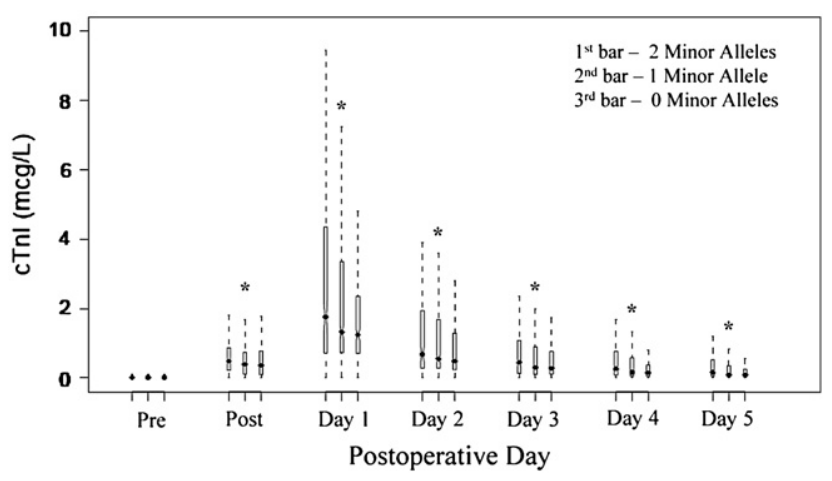

FIGURE 1. Cardiac troponin I level for 9p21 risk allele. The SNP rs 10116277 plotted against cardiac troponin I values on the 7 perioperative time points. The bars on an individual day represent the copies of the risk allele; the first bar represents two copies, the second bar one copy, and the third bar no copy of the risk allele. Each bar represents median with interquartile range and outliers are shown by the dotted lines. $* P<.01$. cTnI, Cardiac troponin I; Pre, preoperatively; Post, immediately after protamine.

clamping and the use of cardioplegic solutions with obligate ischemia and profound coagulation and inflammatory responses. Thus it is perhaps surprising that the genetic evidence of common 9p21 association with both myocardial infarction in nonsurgical populations and PMI supports common molecular mechanisms in both phenotypes.

Similar to the previously published genome-wide association studies in the ambulatory population, the most likely mode of inheritance in our population is an additive model. In contrast, the odds ratios per copy of the risk allele between 1.66 and 1.79 that we observed were significantly higher than the average of 1.3 in associations with cardiovascular disease in the genome-wide association studies in Caucasians. ${ }^{6}$ The variability in risk may be attributed to interaction with environmental factors and the examination of a provoked phenotype; all patients, cases and controls, had $\mathrm{CAD}$ severe enough to warrant CABG surgery. Compared

TABLE 3. Selected 9p21 SNPs associated with PMI-based logistic regression model

\begin{tabular}{|c|c|c|c|c|c|c|c|c|}
\hline \multirow[b]{2}{*}{ SNP } & \multirow[b]{2}{*}{$\begin{array}{c}\text { Chr } 9 \\
\text { position }\end{array}$} & \multirow[b]{2}{*}{$\begin{array}{c}\text { Allele } \\
\text { (minor/major) }\end{array}$} & \multicolumn{2}{|c|}{$\begin{array}{l}\text { Minor allele } \\
\text { frequency }\end{array}$} & \multicolumn{3}{|c|}{$\begin{array}{l}\text { Covariate-adjusted additive } \\
\text { genetic model* }\end{array}$} & \multirow[b]{2}{*}{$\begin{array}{c}\text { Prior nonsurgical MI } \\
\text { studies }\end{array}$} \\
\hline & & & Cases & Controls & $\begin{array}{l}\text { Odds ratio } \\
(95 \% \mathrm{CI})\end{array}$ & Asymptotic $P$ value $\dagger$ & $\begin{array}{c}\text { FWER permuted } \\
P \text { value } \ddagger\end{array}$ & \\
\hline rs10116277 & $22,071,397$ & $\mathrm{G} / \mathrm{T}$ & 0.53 & 0.40 & $1.79(1.29-2.51)$ & .001 & .019 & (7) \\
\hline rs6475606 & $22,071,850$ & $\mathrm{C} / \mathrm{T}$ & 0.53 & 0.40 & $1.79(1.28-2.50)$ & .001 & .020 & \\
\hline rs1333040 & $22,073,404$ & $\mathrm{C} / \mathrm{T}$ & 0.46 & 0.33 & $1.66(1.20-2.28)$ & .002 & .054 & (7) \\
\hline rs2383206 & $22,105,026$ & $\mathrm{~A} / \mathrm{G}$ & 0.50 & 0.38 & $1.67(1.20-2.32)$ & .002 & .061 & (2) \\
\hline rs2383207 & $22,105,959$ & $\mathrm{~A} / \mathrm{G}$ & 0.50 & 0.37 & $1.71(1.23-2.38)$ & .001 & .040 & (7) \\
\hline rs10757278 & $22,114,477$ & $\mathrm{~A} / \mathrm{G}$ & 0.54 & 0.42 & $1.70(1.22-2.38)$ & .001 & .052 & (7) \\
\hline
\end{tabular}

Six most significant SNPs by asymptotic $P$ value selected. For entire SNP list, see Supplement Table 1. SNP, Single nucleotide polymorphism; $P M I$, perioperative myocardial injury; $C h r$, chromosome; $C I$, confidence interval; $F W E R$, family-wise error rate; $M I$, myocardial infarction. *The cohort-specific clinical model consists of predictors from the multivariable model in Table 2. $\dagger$ Asymptotic $P$ value covariate adjusted. $\ddagger$ Family-wise empirical $P$ value is used to adjust for multiple comparisons. 


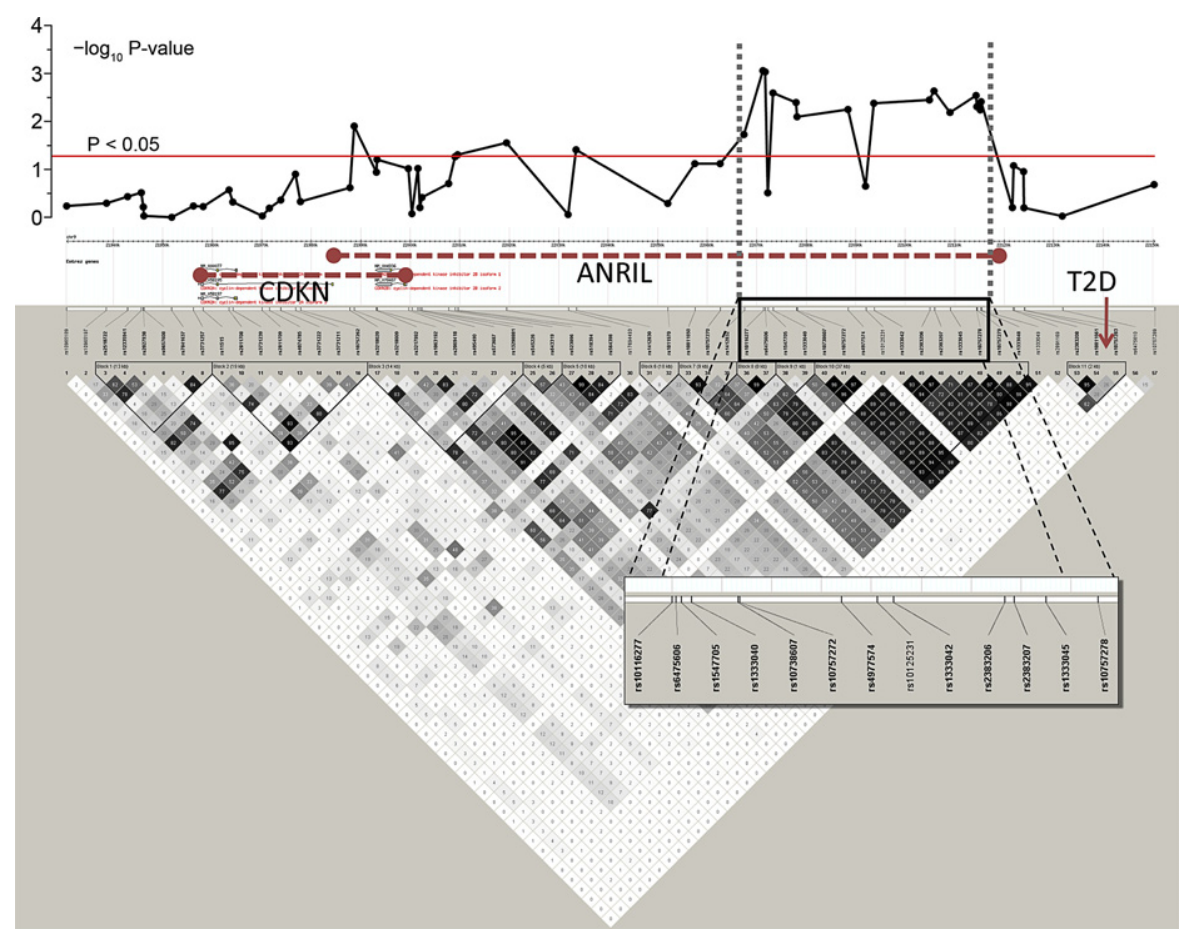

FIGURE 2. Linkage-disequilibrium (LD) plot of $9 \mathrm{p} 21$ region. The upper panel shows negative $\log _{10} P$ values for the association of the individual single nucleotide polymorphism (SNPs) at their physical location with perioperative myocardial injury (PMI), after adjustment in multivariable regression model. The lower panel summarizes the LD structure in the HapMap database (CEU European ancestry). Regions of LD are shaded in gray (moderate LD) or black (strong LD). Predicted haplotype blocks are framed by triangles. The physical location of the genes CDKN2A, CDKN2B, and ANRIL are shown in the HapMap info tack above the SNPs. The type 2 diabetes locus is seen on the far right side of the LD plot, with a nonsignificant association with PMI. $C D K N$, Cyclin-dependent kinase; ANRIL, antisense noncoding RNA gene; $T 2 D$, type 2 diabetes.

with the nonsurgical setting, the incidence of myocardial injury in our population is extremely high.

Although genetic variation in the 9p21 locus is associated with incident cardiovascular disease across many different populations and has a high frequency of the risk allele with a substantial increase in the probability of developing disease with each allele, the utility of screening for this polymorphism to improve risk prediction remains unclear. We observed very substantial incremental improvement of adding 9p21 variants into clinical predictive models of PMI. Similarly, in the Caucasian population of the Atherosclerosis Risk in Communities study $(\mathrm{n}=10,004)$, adding 9p21 variation to traditional risk factors improved CAD risk prediction and reclassification, particularly in higher risk categories. Conversely, in the Women's Genome Health Study $(\mathrm{n}=22,129)$, genetic variation in $9 \mathrm{p} 21 \mathrm{did}$ not improve discrimination or classification of predicted risk. ${ }^{27}$ Therefore, further investigation is warranted before the genetic variation in $9 \mathrm{p} 21$ can be routinely incorporated into perioperative risk prediction models.

\section{Limitations}

We have not yet replicated our findings in a separate cardiac surgical cohort. However, the 9p21 region is the most replicated locus for CAD and myocardial infarction to date across multiple populations. Furthermore, despite examining the entire region, we have observed consistent and strong effect sizes at the same SNPs previously described.

Population stratification, a limitation to all genetic association studies, was addressed by including patients in the analysis who self-reported 4 generations of Caucasian grandparental ancestry. In addition, we tested genomic controls and tested for differences between Northern and Southern Europeans. Accordingly, we believe that this association is not driven by cryptic heterogeneity.

In a study of this magnitude across two centers and many practitioners, differences in treatment will exist. Institutional differences are unlikely to confound the observed association between 9p21 variants and PMI for these reasons: (1) personnel and patients were blinded to genotype and perioperative cTnI measurements performed as part of the study; (2) within this cohort, we did not observe any association between genotype and risk factors for PMI; and (3) within this cohort, it is highly unlikely that concomitant therapies were associated with genotype, with the possible exception of gender, which was included in all models.

Our analysis was limited to Caucasians and therefore these results are not generalizable to other ethnic groups with variable allele frequencies. 


\section{CONCLUSION}

We have identified common genetic variants in $9 \mathrm{p} 21$ within or adjacent to genes $C D K N 2 A / B$ and $A N R I L$, involved in cell-cycle regulation and atherosclerosis, which are significantly and independently associated with PMI in patients undergoing $\mathrm{CABG}$ with $\mathrm{CPB}$. Further investigation is warranted to elucidate the mechanisms by which the variants exert their effects on the development of PMI.

We acknowledge the outstanding contributory efforts of the CABG Genomics research staff: James Gosnell, RN; Kujtim Bodinaku, MD; Jai Madan, MD, MPH; Svetlana Gorbatov, MPH; James Chen, RN; and Isabella Candelaria. We thank all study subjects who participated in the CABG Genomics Program and surgeons who identified their patients.

\section{References}

1. Yusuf S, Hawken S, Ounpuu S, Dans T, Avezum A, Lanas F, et al. Effect of potentially modifiable risk factors associated with myocardial infarction in 52 countries (the INTERHEART study): case-control study. Lancet. 2004;364:937-52.

2. McPherson R, Pertsemlidis A, Kavaslar N, Stewart A, Roberts R, Cox DR, et al. A common allele on chromosome 9 associated with coronary heart disease. Science. 2007;316:1488-91.

3. Consortium WTCC. Genome-wide association study of 14,000 cases of seven common diseases and 3,000 shared controls. Nature. 2007;447:661-78.

4. Samani NJ, Erdmann J, Hall AS, Hengstenberg C, Mangino M, Mayer B, et al. Genomewide association analysis of coronary artery disease. $N$ Engl J Med. 2007;357:443-53.

5. Larson MG, Atwood LD, Benjamin EJ, Cupples LA, RB D'Agostino Sr, Fox CS, et al. Framingham Heart Study $100 \mathrm{~K}$ project: genome-wide associations for cardiovascular disease outcomes. BMC Med Genet. 2007;8(Suppl 1):S5.

6. Schunkert H, Gotz A, Braund P, McGinnis R, Tregouet DA, Mangino M, et al. Repeated replication and a prospective meta-analysis of the association between chromosome 9p21.3 and coronary artery disease. Circulation. 2008;117:1675-84.

7. Helgadottir A, Thorleifsson G, Manolescu A, Gretarsdottir S, Blondal T. A common variant on chromosome 9p21 affects the risk of myocardial infarction. Science. 2007;316:1491-3.

8. Abdullah KG, Li L, Shen GQ, Hu Y, Yang Y, MacKinlay KG, et al. Four SNPS on chromosome 9p21 confer risk to premature, familial CAD and $\mathrm{MI}$ in an American Caucasian population (GeneQuest). Ann Hum Genet. 2008;72(Pt 5):654-7.

9. Broadbent HM, Peden JF, Lorkowski S, Goel A, Ongen H, Green F, et al. Susceptibility to coronary artery disease and diabetes is encoded by distinct, tightly linked SNPs in the ANRIL locus on chromosome 9 p. Hum Mol Genet. 2008; 17:806-14.

10. Pasmant E, Laurendeau I, Heron D, Vidaud M, Vidaud D, Bieche I. Characterization of a germ-line deletion, including the entire INK4/ARF locus, in a melanomaneural system tumor family: identification of ANRIL, an antisense noncoding RNA whose expression coclusters with ARF. Cancer Res. 2007;67:3963-9.

11. Kim WY, Sharpless NE. The regulation of INK4/ARF in cancer and aging. Cell. 2006;127:265-75.
12. Devereaux PJ, Goldman L, Cook DJ, Gilbert K, Leslie K, Guyatt GH. Perioperative cardiac events in patients undergoing noncardiac surgery: a review of the magnitude of the problem, the pathophysiology of the events and methods to estimate and communicate risk. CMAJ. 2005;173:627-34.

13. Podgoreanu MV, White WD, Morris RW, Mathew JP, Stafford-Smith M, Welsby IJ, et al. Inflammatory gene polymorphisms and risk of postoperative myocardial infarction after cardiac surgery. Circulation. 2006;114(1 Suppl): I275-81.

14. Collard CD, Shernan SK, Fox AA, Bernig T, Chanock SJ, Vaughn WK, et al. The MBL2 "LYQA secretor"' haplotype is an independent predictor of postoperative myocardial infarction in whites undergoing coronary artery bypass graft surgery. Circulation. 2007;116(11 Suppl):I106-12.

15. Barrett JC, Fry B, Maller J, Daly MJ. Haploview: analysis and visualization of LD and haplotype maps. Bioinformatics. 2005;21:263-5.

16. Saxena R, Voight BF, Lyssenko V, Burtt NP, de Bakker PI, Chen H, et al. Genome-wide association analysis identifies loci for type 2 diabetes and triglyceride levels. Science. 2007;316:1331-6.

17. Kalinina N, Agrotis A, Antropova Y, Ilyinskaya O, Smirnov V, Tararak E, et al. Smad expression in human atherosclerotic lesions: evidence for impaired TGFbeta/Smad signaling in smooth muscle cells of fibrofatty lesions. Arterioscler Thromb Vasc Biol. 2004;24:1391-6.

18. Liu Y, Sanoff HK, Cho H, Burd CE, Torrice C, Mohlke KL, et al. INK4/ARF transcript expression is associated with chromosome $9 \mathrm{p} 21$ variants linked to atherosclerosis. PLoS ONE. 2009;4:e5027.

19. Raffetto JD, Leverkus M, Park HY, Menzoian JO. Synopsis on cellular senescence and apoptosis. J Vasc Surg. 2001;34:173-7.

20. Ye S, Willeit J, Kronenberg F, Xu Q, Kiechl S. Association of genetic variation on chromosome 9p21 with susceptibility and progression of atherosclerosis: a population-based, prospective study. J Am Coll Cardiol. 2008;52:378-84.

21. Thompson AR, Golledge J, Cooper JA, Hafez H, Norman PE, Humphries SE. Sequence variant on $9 \mathrm{p} 21$ is associated with the presence of abdominal aortic aneurysm disease but does not have an impact on aneurysmal expansion. Eur $J$ Hum Genet. 2009; 17:391-4. Epub 2008 Oct 15.

22. Helgadottir A, Thorleifsson G, Magnusson KP, Gretarsdottir S, Steinthorsdottir V, Manolescu A, et al. The same sequence variant on 9p21 associates with myocardial infarction, abdominal aortic aneurysm and intracranial aneurysm. Nat Genet. 2008;40:217-24.

23. Samani NJ, Raitakari OT, Sipila K, Tobin MD, Schunkert H, Juonala M, et al. Coronary artery disease-associated locus on chromosome 9p21 and early markers of atherosclerosis. Arterioscler Thromb Vasc Biol. 2008;28: 1679-83.

24. Priebe HJ. Perioperative myocardial infarction-aetiology and prevention. $\mathrm{Br} \mathrm{J}$ Anaesth. 2005;95:3-19.

25. Landesberg G, Luria MH, Cotev S, Eidelman LA, Anner H, Mosseri M, et al. Importance of long-duration postoperative ST-segment depression in cardiac morbidity after vascular surgery. Lancet. 1993;341:715-9.

26. Braunwald E, Antman EM, Beasley JW, Califf RM, Cheitlin MD, Hochman JS, et al. ACC/AHA guidelines for the management of patients with unstable angina and non-ST-segment elevation myocardial infarction. A report of the American College of Cardiology/American Heart Association Task Force on Practice Guidelines (Committee on the Management of Patients With Unstable Angina). J Am Coll Cardiol. 2000;36:970-1062.

27. Paynter NP, Chasman DI, Buring JE, Shiffman D, Cook NR, Ridker PM. Cardiovascular disease risk prediction with and without knowledge of genetic variation at chromosome 9p21.3. Ann Intern Med. 2009;150:65-72. 
TABLE E1. Sixty 9p21 SNPs considered for association with PMI based on logistic regression model

\begin{tabular}{|c|c|c|c|c|c|c|c|}
\hline \multirow[b]{2}{*}{ SNP } & \multirow[b]{2}{*}{ Chr 9 position } & \multirow[b]{2}{*}{$\begin{array}{c}\text { Allele } \\
\text { (minor/major) }\end{array}$} & \multicolumn{2}{|c|}{ Minor allele frequency } & \multicolumn{3}{|c|}{$\begin{array}{c}\text { Covariate-adjusted additive } \\
\text { genetic model }^{*} \\
\end{array}$} \\
\hline & & & Cases & Controls & Odds ratio $(95 \%$ CI) & $\begin{array}{c}\text { Asymptotic } \\
P \text { value } \dagger\end{array}$ & $\begin{array}{c}\text { FWER permuted } \\
P \text { value } \ddagger \\
\end{array}$ \\
\hline rs10965189 & 21930588 & $\mathrm{~A} / \mathrm{C}$ & 0.03 & 0.04 & $0.76(0.30-1.93)$ & .559 & 1.000 \\
\hline rs10965197 & 21938666 & $\mathrm{~T} / \mathrm{C}$ & 0.45 & 0.42 & $1.11(0.79-1.55)$ & .540 & 1.000 \\
\hline rs2518722 & 21942926 & $\mathrm{~T} / \mathrm{C}$ & 0.27 & 0.31 & $0.82(0.56-1.20)$ & .310 & 1.000 \\
\hline rs12335941 & 21945669 & G/A & 0.37 & 0.42 & $0.82(0.58-1.16)$ & .266 & 1.000 \\
\hline rs2027938 & 21946078 & $\mathrm{~A} / \mathrm{G}$ & 0.25 & 0.28 & $0.89(0.61-1.30)$ & .535 & 1.000 \\
\hline rs9657608 & 21946230 & $\mathrm{~T} / \mathrm{C}$ & 0.09 & 0.10 & $0.98(0.56-1.72)$ & .952 & 1.000 \\
\hline rs7041637 & 21951866 & $\mathrm{~A} / \mathrm{C}$ & 0.31 & 0.30 & $1.02(0.71-1.47)$ & .916 & 1.000 \\
\hline rs3731257 & 21956221 & $\mathrm{~T} / \mathrm{C}$ & 0.29 & 0.26 & $1.11(0.77-1.61)$ & .569 & 1.000 \\
\hline rs11515 & 21958199 & $\mathrm{G} / \mathrm{C}$ & 0.15 & 0.17 & $0.86(0.55-1.33)$ & .498 & 1.000 \\
\hline rs2811708 & 21963422 & $\mathrm{~T} / \mathrm{G}$ & 0.26 & 0.31 & $0.79(0.54-1.15)$ & .213 & .996 \\
\hline rs3731239 & 21964218 & $\mathrm{C} / \mathrm{T}$ & 0.35 & 0.31 & $1.16(0.81-1.64)$ & .416 & 1.000 \\
\hline rs2811709 & 21970151 & $\mathrm{~A} / \mathrm{G}$ & 0.12 & 0.13 & $0.95(0.59-1.54)$ & .838 & 1.000 \\
\hline rs4074785 & 21971583 & $\mathrm{~A} / \mathrm{G}$ & 0.10 & 0.09 & $1.13(0.66-1.93)$ & .657 & 1.000 \\
\hline rs3731222 & 21973914 & $\mathrm{G} / \mathrm{A}$ & 0.13 & 0.16 & $0.81(0.50-1.32)$ & .400 & 1.000 \\
\hline rs3731211 & 21976847 & $\mathrm{~A} / \mathrm{T}$ & 0.26 & 0.33 & $0.72(0.50-1.06)$ & .097 & .907 \\
\hline rs 10757262 & 21977874 & $\mathrm{~T} / \mathrm{A}$ & 0.14 & 0.16 & $0.83(0.52-1.30)$ & .409 & 1.000 \\
\hline rs3218020 & 21987872 & $\mathrm{~T} / \mathrm{C}$ & 0.38 & 0.41 & $0.81(0.58-1.13)$ & .217 & .997 \\
\hline rs3218009 & 21988757 & $\mathrm{C} / \mathrm{G}$ & 0.14 & 0.08 & $1.87(1.15-3.04)$ & .011 & .261 \\
\hline rs3217992 & 21993223 & $\mathrm{~A} / \mathrm{G}$ & 0.40 & 0.45 & $0.76(0.54-1.07)$ & .111 & .936 \\
\hline rs1063192 & 21993367 & $\mathrm{C} / \mathrm{T}$ & 0.41 & 0.34 & $1.43(1.01-2.01)$ & .045 & .670 \\
\hline rs2069418 & 21999698 & $\mathrm{C} / \mathrm{G}$ & 0.43 & 0.36 & $1.38(0.98-1.94)$ & .063 & .787 \\
\hline rs495490 & 22000412 & $\mathrm{C} / \mathrm{T}$ & 0.10 & 0.10 & $1.08(0.63-1.86)$ & .790 & 1.000 \\
\hline rs573687 & 22001642 & $\mathrm{~T} / \mathrm{C}$ & 0.35 & 0.29 & $1.38(0.96-1.96)$ & .079 & .855 \\
\hline rs13298881 & 22002051 & $\mathrm{C} / \mathrm{T}$ & 0.13 & 0.14 & $0.87(0.54-1.41)$ & .581 & 1.000 \\
\hline rs545226 & 22002422 & $\mathrm{C} / \mathrm{T}$ & 0.43 & 0.46 & $0.86(0.61-1.19)$ & .357 & 1.000 \\
\hline rs643319 & 22007836 & $\mathrm{~T} / \mathrm{G}$ & 0.45 & 0.41 & $1.25(0.90-1.76)$ & .188 & .992 \\
\hline rs523096 & 22009129 & $\mathrm{C} / \mathrm{T}$ & 0.43 & 0.35 & $1.43(1.02-2.00)$ & .038 & .604 \\
\hline rs518394 & 22009673 & $\mathrm{G} / \mathrm{C}$ & 0.43 & 0.36 & $1.46(1.03-2.05)$ & .031 & .539 \\
\hline rs564398 & 22019547 & G/A & 0.40 & 0.32 & $1.52(1.07-2.15)$ & .020 & .398 \\
\hline rs17694493 & 22031998 & $\mathrm{G} / \mathrm{C}$ & 0.14 & 0.14 & $0.94(0.59-1.51)$ & .801 & 1.000 \\
\hline rs1412830 & 22033612 & $\mathrm{~A} / \mathrm{G}$ & 0.36 & 0.29 & $1.48(1.05-2.09)$ & .027 & .498 \\
\hline rs1011970 & 22052134 & $\mathrm{~T} / \mathrm{G}$ & 0.15 & 0.18 & $0.85(0.55-1.32)$ & .477 & 1.000 \\
\hline rs 10811650 & 22057593 & $\mathrm{~A} / \mathrm{G}$ & 0.55 & 0.49 & $1.37(0.98-1.90)$ & .064 & .792 \\
\hline rs 10757270 & 22062719 & $\mathrm{~A} / \mathrm{G}$ & 0.55 & 0.48 & $1.36(0.98-1.89)$ & .063 & .787 \\
\hline rs1412832 & 22067543 & $\mathrm{C} / \mathrm{T}$ & 0.31 & 0.22 & $1.58(1.10-2.28)$ & .013 & .290 \\
\hline rs10116277 & 22071397 & $\mathrm{G} / \mathrm{T}$ & 0.53 & 0.40 & $1.79(1.29-2.51)$ & .001 & .019 \\
\hline rs6475606 & 22071850 & $\mathrm{C} / \mathrm{T}$ & 0.53 & 0.40 & $1.79(1.28-2.50)$ & .001 & .020 \\
\hline rs 1547705 & 22072375 & $\mathrm{C} / \mathrm{A}$ & 0.13 & 0.16 & $0.77(0.48-1.23)$ & .276 & 1.000 \\
\hline rs1333040 & 22073404 & $\mathrm{C} / \mathrm{T}$ & 0.46 & 0.33 & $1.66(1.20-2.28)$ & .002 & .054 \\
\hline rs10738607 & 22078094 & $\mathrm{~A} / \mathrm{G}$ & 0.53 & 0.41 & $1.65(1.19-2.30)$ & .003 & .077 \\
\hline rs 10757272 & 22078260 & $\mathrm{C} / \mathrm{T}$ & 0.52 & 0.41 & $1.59(1.14-2.21)$ & .006 & .157 \\
\hline rs4977574 & 22088574 & $\mathrm{~A} / \mathrm{G}$ & 0.52 & 0.40 & $1.63(1.17-2.27)$ & .004 & .103 \\
\hline rs10125231 & 22092128 & $\mathrm{~A} / \mathrm{G}$ & 0.02 & 0.04 & $0.53(0.16-1.75)$ & .297 & 1.000 \\
\hline rs1333042 & 22093813 & $\mathrm{~A} / \mathrm{G}$ & 0.50 & 0.38 & $1.65(1.19-2.30)$ & .003 & .079 \\
\hline rs2383206 & 22105026 & $\mathrm{~A} / \mathrm{G}$ & 0.50 & 0.38 & $1.67(1.20-2.32)$ & .002 & .061 \\
\hline rs2383207 & 22105959 & $\mathrm{~A} / \mathrm{G}$ & 0.50 & 0.37 & $1.71(1.23-2.38)$ & .002 & .040 \\
\hline rs 1333045 & 22109195 & $\mathrm{~T} / \mathrm{C}$ & 0.50 & 0.39 & $1.63(1.17-2.28)$ & .004 & .113 \\
\hline rs 10757278 & 22114477 & $\mathrm{~A} / \mathrm{G}$ & 0.54 & 0.42 & $1.70(1.22-2.38)$ & .002 & .052 \\
\hline rs 10757279 & 22114630 & $\mathrm{~A} / \mathrm{G}$ & 0.54 & 0.42 & $1.65(1.18-2.32)$ & .004 & .098 \\
\hline rs1333048 & 22115347 & $\mathrm{~A} / \mathrm{C}$ & 0.51 & 0.40 & $1.64(1.18-2.30)$ & .004 & .098 \\
\hline rs1333049 & 22115503 & $\mathrm{C} / \mathrm{G}$ & 0.54 & 0.42 & $1.67(1.20-2.33)$ & .003 & .066 \\
\hline
\end{tabular}


Covariate-adjusted additive

Minor allele frequency

\begin{tabular}{|c|c|c|c|c|c|c|c|}
\hline \multirow[b]{2}{*}{ SNP } & \multirow[b]{2}{*}{ Chr 9 position } & \multirow[b]{2}{*}{$\begin{array}{c}\text { Allele } \\
\text { (minor/major) }\end{array}$} & \multicolumn{2}{|c|}{ Minor allele frequency } & \multicolumn{3}{|c|}{ genetic model* } \\
\hline & & & Cases & Controls & Odds ratio $(95 \%$ CI $)$ & $\begin{array}{c}\text { Asymptotic } \\
P \text { value } \dagger\end{array}$ & $\begin{array}{c}\text { FWER permuted } \\
P \text { value } \ddagger\end{array}$ \\
\hline rs2891169 & 22121825 & $\mathrm{G} / \mathrm{A}$ & 0.39 & 0.40 & $0.92(0.66-1.28)$ & .626 & 1.000 \\
\hline rs2383208 & 22122076 & $\mathrm{G} / \mathrm{A}$ & 0.14 & 0.19 & $0.66(0.41-1.06)$ & .084 & .870 \\
\hline rs10811661 & 22124094 & $\mathrm{C} / \mathrm{T}$ & 0.13 & 0.18 & $0.68(0.42-1.10)$ & .117 & .946 \\
\hline rs 10757283 & 22124172 & $\mathrm{~T} / \mathrm{C}$ & 0.43 & 0.44 & $0.92(0.66-1.28)$ & .603 & 1.000 \\
\hline rs6475610 & 22131894 & $\mathrm{~T} / \mathrm{C}$ & 0.49 & 0.49 & $0.99(0.72-1.36)$ & .947 & 1.000 \\
\hline rs 10757289 & 22150454 & $\mathrm{C} / \mathrm{G}$ & 0.46 & 0.41 & $1.23(0.89-1.71)$ & .214 & .997 \\
\hline rs1679013 & 22196987 & $\mathrm{~T} / \mathrm{C}$ & 0.51 & 0.50 & $1.08(0.78-1.50)$ & .659 & 1.000 \\
\hline rs10113901 & 22364032 & $\mathrm{C} / \mathrm{T}$ & 0.49 & 0.49 & $0.97(0.70-1.34)$ & .837 & 1.000 \\
\hline rs7046709 & 22366970 & $\mathrm{G} / \mathrm{A}$ & 0.34 & 0.34 & $1.00(0.71-1.41)$ & .987 & 1.000 \\
\hline
\end{tabular}

Six most significant SNPs by asymptotic $P$ value selected for Table 1 are shaded in gray. SNP, Single nucleotide polymorphism; $P M I$, perioperative myocardial injury; $C h r$, chromosome; $C I$, confidence interval; $F W E R$, family-wise error rate. ${ }^{*}$ The cohort-specific clinical model consists of predictors from the multivariable model in Table 2. $\dagger$ Asymptotic $P$ value covariate adjusted. $\ddagger$ Family-wise empirical $P$ value is used to adjust for multiple comparisons. 